\title{
Nutrition and Blood Glucose Response of Food Formulated Four Types of Local Flour East Kalimantan Added Plant Extracts Tiwai (Eleutherina americana Merr)
}

\author{
Bernatal Saragih ${ }^{1}$, Maulida Rachmawati ${ }^{1}$, Marwati ${ }^{1}$ and Suhardi $^{2}$ \\ ${ }^{I}$ Department of Agricultural Product and Technology, Faculty of Agriculture Mulawarman University Jl. Pasir \\ Balengkong Kampus Gunung Kelua. Samarinda, East Kalimantan, Indonesia 75123 \\ ${ }^{2}$ Department of Animal Husbandry, Faculty of Agriculture Mulawarman University Jl. Pasir Balengkong \\ Kampus Gunung Kelua. Samarinda, East Kalimantan, Indonesia 75123
}

\begin{abstract}
Foods that have a greater effect on blood glucose levels, therefore the research of food sources that have a low potential glycemic very important example tiwai plant extract, bananas (hump), striatus fish, and sweet potatoes. The research was conducted on the test phytochemicals, nutritional composition, making food products cereal and test on human subjects to determine the blood glucose response. Phytochemical test results showed that steroids are not on lai, tiwai, banana weevil, catfish and sweet potato. Saponins found only in lai and banana weevil. Flavonoids are not detected in striatus fish, alkaloids were not detected in striatus fish and sweet potato. Test sonsoris most preferred flour is the yellow sweet potato flour, then a row of bananas, lai, and catfish. Composite flour is most preferred by the panelists with a ratio lai: banana weevil: catfish: sweet potato (1:2: 1: 2). Nutrient composition of cereal carbohydrates (75.22\%), protein (6.57\%), fat (3.26\%), water content (10.15\%), ash content (1.45\%) and crude fiber (3,35\%). A decrease in blood glucose after consumption of 60 minutes energen (commercial product) is $31.84 \mathrm{mg} / \mathrm{dL}$, while cereal product this research equal to $4.67 \mathrm{mg} / \mathrm{dL}$. The energy produced per $1 \mathrm{~g}$ of cereal products of this research is $3.56 \mathrm{kcal}$ while Energen cereal (commercial product) $4.48 \mathrm{kcal}$. Cereal base on local products are potential used as functional food due to a decrease in blood glucose more slowly than the commercial product.
\end{abstract}

Keywords: nutrition, blood glucose response, cereal, local flour

\section{Introduction}

Diabetes constitutes an increasingly prevalent disease, dramatically associated with an enhanced mortality risk in the developed world. Various problems associated with the occurrence of multiple nutritional problems lately become the focus of attention of health and nutrition experts. Economic improvement in line with lifestyle changes including diet. Propensity to consume food that is not balanced, high fat intake, low in vitamins, minerals and dietary fiber are important factors that contribute to excess weight (overweight) and obesity $[1,10]$. Obesity is a risk factor for coronary heart disease (CHD). To address the problem of obesity and hypercholesterolemia as well as their impact on CHD using a functional food product development has not been much research done. Development of functional food products are safer than the use of chemicals. Efforts to lower cholesterol with food sources of biological products such as tiwai extract of these plants and successfully lowers cholesterol [1].

Consumer demand for functional foods and new food becomes very important for the development of food for special needs to overcome these problems. The proposed changes to the Nutrition Facts Label by the US Food and Drug Administration will include information on added sugars for the first time. Most added sugars came from foods obtained from stores. The proposed changes to the Nutrition Facts Label should capture the bulk of added sugars in the US food supply, which suggests that the recommended changes have the potential to reduce added sugars consumption [2].

Exploration of a variety of plants are useful in the development of new products mainly available in East Kalimantan Indonesia in particular is very important. The development of food such as grains lai, sweet potato, banana weevil, and Haruan of fish as a protein source, became an important part in preserving the culture of eating as well as food and nutrition needs of the community. Results of a study conducted by Saragih 2014 [1] showed that the tiwai extract can lower cholesterol patients hipercholesterolemia after ingestion for 7 days with administration of 2 times a day morning and afternoon. Sweet potatoes are also rich in carbohydrates bulbs and can serve as a prebiotic in the body so it is potential to be used as a functional food ingredient. Haruan fish from several studies have shown can increase serum albumin in maternal postpartum understood. Utilization lai seeds as flour ingredient in the formulation of this research to utilize waste lai seeds and product diversification in support of food availability, especially grains typical East Kalimantan (Kutai Regency). 
The varieties of bananas kepok (Musa albisiana Colla) produces flour weevil with the best quality compared to banana varieties Musa Textilia (king), mahuli (Musa acuminata colla), milk (Musa sp) and Ambon (Musa paradisiaca), Kepok banana flour has a lower water content (0.99\%) and crude fiber content (29.62\%) higher dibandingakan with other banana weevil flour. Age harvesting banana weevil kepok influence on the quality of flour banana weevil mainly on water content, ash content, water absorption and wetability time. Age harvesting banana weevil kepok after harvesting which provide the best quality with a lower water content is $1.02 \%$, and the water absorption was higher by $254.3 \%$ [3].

Food formulations sourced from East Kalimantan's nature as a basic ingredient flake cereal becomes very important, especially for nutrients complement each other in the form of cereal flakes into a new functional food. The need for health food, especially food that is rich in nutrient uptake becomes an important part in the exploration of exotic foodstuffs East Kalimantan. Scientific evidence that the test done phytochemicals, nutritional composition, characteristics of flour, food products formulation of lepiu with lai (Durio kutejensis), extract tiwai (Eleutherine americana Merr), banana tuber (Musa paradisiaca Linn), yellow sweet potato (Ipomoea batatas (L.) Lamb) and haruan fish (Ophiocephalus striatus) and test blood sugar response of subject.

\subsection{Materials}

\section{Material And Methods}

Materials used in this study i.e: lai, banana weevil, striatus fish, sweet potato, Meyer reagents, reagent Wagner, sulphate acid, chloroform, glacial acetic acid, magnesium powder, amyl alcohol, alcohol, hydrochloric acid, ethanol, reagent $\mathrm{FeCl}_{3}$ (Merck) and materials for proximate analysis as well as samples of cereal dough ingredients. The tools used were oven, spectrometers, vortex, sentrifius, glucose test (accu check) and digital balance.

\subsection{Flour Processing}

The work steps in the processing of lai, banana weevil, sweet potato and fish haruan are as follows: Materials are selected and sorted and cleaned. Then steamed for 15 minutes then drained. Then dried in an oven for 18 hours at a temperature of 70 to dry. After dry milling and sieving performed ( 80 mesh) to obtain flour

\subsection{Formulation of flour}

The organoleptic evaluation of all the 12 composite flour was conducted by 25 penellist. A five point numerical score card was used on a scale of 1-5 ranging from poor to excellent to rate in terms of appearance, color and texture and was totaled to know most acceptable variation.

\subsection{Cereal Process}

Making cereal made on the composition of most of the good results of organoleptic panelist that comparison flour lai: banana weevil: striatus fish and sweet potato $(1: 2: 1: 2)$

1) All the dry ingredients (flour formulation 250 grams, 20 grams of milk powder, vanilla 1 gram and 2 grams of salt), into a single, mix until blended.

2) Added 2 chicken eggs and $50 \mathrm{~g}$ of margarine that has been melted

3) Tiwai $200 \mathrm{ml}$ of extract was added and stirred mix until well blended. (Extracts of obtained from Tiwai previously cleaned, in cut with a size of $2 \mathrm{~mm}$ further drying for 2 days at room temperature. Then every 3 grams of dried Tiwai added with $200 \mathrm{ml}$ of hot water in order to obtain extracts Tiwai.

4) Was made on ekstuder pasta noodle dough by using a molds of the smallest

5) Then the molds thread noodles made square and rectangular cut after it in the oven until the moisture content of $1-3 \%$

6) Mature cereal crushed into flakes then performed packaging and sensory test, carbohydrate content, fat content, protein content, moisture content, ash content and fiber.

\subsection{Phytochemical Determination}

Qualitative phytochemical analysis performed on the four types of flour. The phenolic, alkaloid, Flavonoid and steroid were determined using the method described by AOAC 2006 [6]. Saponin analysis was conducted with the flour is diluted with distilled water and made up to $20 \mathrm{ml}$. The suspension is shaken in a graduated cylinder for 15 minutes. A two cm layer of foam indicates the presence of saponins [14].

\subsection{Bulk Density}

Bulk density measurements performed by weighing the material / weight of starch (a gram) included in the measuring cup $50 \mathrm{ml}$ up to the mark and calibration. Then measuring the weight of the measuring cup flour (b grams). Bulk density is calculated using the formula: 


$$
\text { Bulk Density }=\quad \frac{(b-a) \text { gram }}{50 \mathrm{ml}}
$$

Remarks:

$\mathrm{a}=$ weight of the measuring cup is empty

$\mathrm{b}=$ weight of the measuring cup containing the sample

\subsection{Wettability Time}

One gram of each of the flour samples was weighed out using an analytical balance and were each added into a $25 \mathrm{ml}$ graduated measuring cylinder with a diameter of $1 \mathrm{~cm}$. the finger was then placed over the open end of the cylinder in each case, inverted and was clamped at a height of $10 \mathrm{~cm}$ from the surface of a 600 $\mathrm{ml}$ beaker containing $500 \mathrm{ml}$ of distilled water. The finger was then removed and the test sample was allowed to be dumped. The wettability was recorded as the time required for the sample to become completely wet [7].

\subsection{Water absorbtion capacity}

One gram of each of the flour samples was weighed out with the aid of an analytical balance and mixed with $10 \mathrm{ml}$ of distilled water or refined palm oil with known density in a weighed $20 \mathrm{ml}$ centrifuge tube for each sample. The resulted slurries were agitated on a vortex mixer for 2 minutes, allowed to stand at a temperature of 280c for 30 minutes and then centrifuged supernatants were decanted and discarded. The adhering drops of the water or oil were removed and the tubes weighed in each case. The weight of water absorbed by $1 \mathrm{~g}$ of each of the flour samples was calculated and expressed as water absorption capacity of the samples[7].

\subsection{Nutrition Analysis}

The percentage moisture, protein, ether extract, Ash and Crude fibre content were analysed according to the method of AOAC 2006 [6]. While the percentage carbohydrate was estimated by difference $\%$ carbohydrate $=100-(\%$ moisture $+\%$ Ash $+\%$ crude fibre $+\%$ crude protein $+\%$ fat $)$.

Energy $(\mathrm{kcal})=$ calculations carried summation of multiplication $4 \mathrm{x}$ carbohydrate, $4 \mathrm{x}$ protein, and $9 \mathrm{x}$ fat

\subsection{Response Test of Blood Sugar}

Test of blood glucose response of selected cereal with cereal Energen comparison done on 11 subjects students who have normal blood glucose. Cereals produced is by giving blood glycemic response portion $(29 \mathrm{~g}$ cereal) to volunteers who had undergone a full fasting except water during the night (around 20:00 to 08:00). Volunteers are individuals who used normal, no diabetes, as many as 11 people, the method used to determine the glycemic response, $[15,4]$ the blood sampling interval of 30 minutes 5 times (minutes to 0, 30, 60, 90 and 120) were $50 \mu \mathrm{l}$ (finger-prick capillary blood samples method). Then the 3-day interval of the same is done by giving $29 \mathrm{~g}$ of cereal Energen (standard) this is done to compare the blood glucose response between the cereals produced by the commercial cereal (cereal energen).

\subsection{Phytochemicals}

\section{Results}

The test results of the phytochemical lai, tiwai, banana weevil, fish and sweet potato. Haruan fish shows that the component steroids and saponins only detected in lepiu, lai and banana weevil. Flavonoids are not detected in fish and alkaloid was not detected in fish and sweet potato (Table 1)

Table 1. Phytochemicals Test Results

\begin{tabular}{|l|c|c|c|c|c|}
\hline \multirow{2}{*}{ Samples } & \multicolumn{5}{|c|}{ Phytochemicals } \\
\cline { 2 - 6 } & Steroids & Saponins & Flavonoids & Phenol & Alkaloids \\
\hline Lai seed & - & ++ & ++ & + & +++ \\
\hline Tiwai & - & - & +++ & +++ & ++ \\
\hline Banana Weevil & - & + & +++ & +++ & + \\
\hline Ikan Haruan & - & - & - & - & - \\
\hline Ubi Jalar Kuning & - & - & + & + & - \\
\hline
\end{tabular}

Remarks:

Lai seed (Durio kutejensis), Tiwai (Eleutherine americana Merr), Bonggol Pisang/Banana weevil (Musa paradisiaca Linn), Ubi Jalar Kuning/sweet yellow potato(Ipomoea batatas (L.) Lamb), Ikan Haruan/haruan fish (Ophiocephalus striatus), (-) not detcted, (+)detected less to very strong. 
Nutrition and Blood Glucose Response of Food Formulated Four Types of Local Flour East ..

\subsection{Nutrition of Flour}

The results of the analysis of the nutritional components include carbohydrates, protein, fat, moisture content, ash content and fiber. The highest carbohydrate content obtained on banana weevil flour, sweet potato flour then, lai and lepiu while the lowest is fish. Protein component of highest to lowest row of fish, lai, sweet potato, and banana weevil lepiu. Obtained at the highest fiber content of flour banana weevil and yellow sweet potato (Table 2).

Table 2. Nutrition analysis and energy of flour

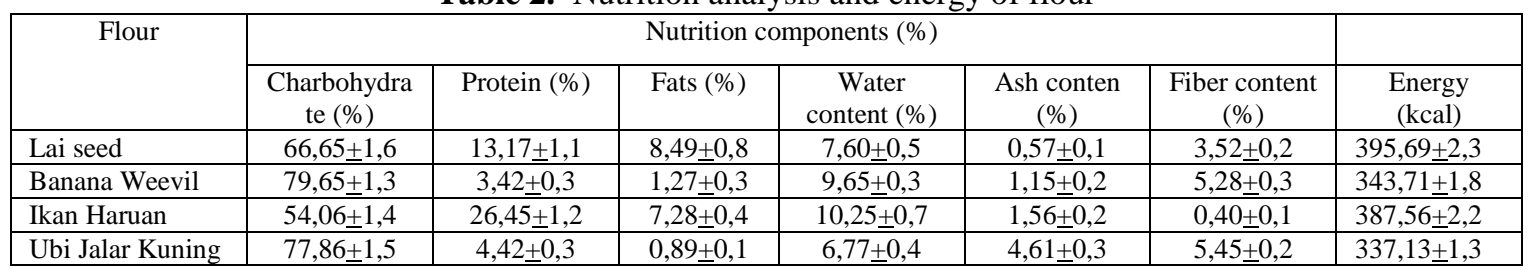

Remarks:

Lai seed (Durio kutejensis), Tiwai (Eleutherine americana Merr), Bonggol Pisang/Banana weevil (Musa paradisiaca Linn), Ubi Jalar Kuning/sweet yellow potato(Ipomoea batatas (L.) Lamb), Ikan Haruan/Haruan fish (Ophiocephalus striatus)

\subsection{Rendemen and Functional Properties of Flour}

Rendemen flour obtained on sweet potatoes then haruan fish, lai, and the banana weevil. Kamba highest density obtained at lai and sweet potatoes while the water absorption capacity was obtained on sweet potatoes and catfish. Solubility also highest in haruan fish and sweet potato (Table 3).

Table 3. Rendemen and functional properties of flour

\begin{tabular}{|l|c|c|c|c|}
\hline \multirow{2}{*}{ Flour } & \multicolumn{4}{|c|}{ Solubility (second) } \\
\cline { 2 - 5 } & $\begin{array}{c}\text { Rendemen } \\
(\%)\end{array}$ & $\begin{array}{c}\text { Density Kamba } \\
(\mathrm{ml} / \text { gram })\end{array}$ & $\begin{array}{c}\text { Water absorbtion } \\
\text { capacity (\%) }\end{array}$ & 69,35 \\
\hline Lai seed & 18,46 & 0,46 & 18 & 66,39 \\
\hline Banana Weevil & 15,62 & 0,40 & 30 & 51,78 \\
\hline Ikan Haruan & 21,42 & 0,30 & 35 & 58,74 \\
\hline Ubi Jalar Kuning & 30,00 & 0,44 & 36 & \\
\hline
\end{tabular}

\subsection{Sensory Properties of flour}

The results of sensory properties on flour produced was obtained for the color most preferred by the panelists is sweet potato flour and flour banana weevil. Aroma on banana weevil most preferred by the panelists compared with other flour. Based on the rankings obtained organoleptic sweet potato flour is most preferred by consumers and then the flour banana weevil, lai, and haruan of fish (Table 4).

Tabel 4. Sensory Properties of Flour

\begin{tabular}{|l|c|c|c|c|c|}
\hline & Colour & Aroma & Texture & Average & Ranking \\
\hline Lai seed & 2.8 & 3.4 & 3.6 & 3.27 & 3 \\
\hline Banana Weevil & 4 & 4 & 3.6 & 3.87 & 2 \\
\hline Ikan Haruan & 3 & 3 & 3.4 & 3.10 & 4 \\
\hline Ubi Jalar Kuning & 4.4 & 3 & 3.8 & 4.00 & 1 \\
\hline
\end{tabular}

Remarks:

1 = Dislike, 2 = rather dislike, 3 = rather like, 4 = likes, 5 = Very Like

The results shows the best formula based on the ratio of flour organoleptic lai: bananas weevil: haruan fish and sweet potatoes (1:2:1:2). Subsequently best Fromulasi then proceed to make cereal.

The results of organoleptic test by 25 panelists on cereals with composite flour elected by comparison flour lai: bananas weevil: haruan fish and sweet potatoes (1:2:1:2) was obtained color with rather like, aroma like, taste rather like and a texture like

\subsection{Nutrition composition of cereal}

Nutrient composition of sereal had higher levels of carbohydrates $(75.22 \%)$, protein $(6.57 \%)$, fat $(3.26 \%)$, water $(10.15 \%)$, ash $(1.45 \%)$, crude fiber $(3,35 \%)$ and energy $356,5 \mathrm{kcal}$ (Table 5) 
Nutrition and Blood Glucose Response of Food Formulated Four Types of Local Flour East ..

Tabel 5. Compoisition nutrition of cereal product research

\begin{tabular}{|c|c|c|c|c|c|c|c|}
\hline \multirow{2}{*}{ Cereal } & \multicolumn{5}{|c|}{ Nutrition composition } & \\
\cline { 2 - 7 } & Carbohydrate (\%) & Protein (\%) & Fat (\%) & Water (\%) & Ash (\%) & Fiber (\%) & Energy (kcal) \\
\hline $75,22 \pm 1,8$ & $6,57 \pm 0,7$ & $3,26 \pm 0,4$ & $10,15 \pm 1,2$ & $1,45 \pm 0,3$ & $3,35 \pm 0,3$ & $356,5 \pm 2,2$ \\
\hline
\end{tabular}

\subsection{Blood Sugar Levels Response After Consumption of Cereals Product Research and Commercial Product}

Blood glucose during fasting $(0 \mathrm{~min})$ the average subject $81,25 \mathrm{mg} / \mathrm{dL}$ with the lowest was $83 \mathrm{mg} / \mathrm{dL}$, while the highest was $99 \mathrm{mg} / \mathrm{d}$ (Table 6). Difference rise in blood glucose when eating cereal before the lepiu of 13.42 $\mathrm{mg} / \mathrm{dL}$. Average increase in blood glucose occurred after $120 \mathrm{~min}$ compared with $0 \mathrm{~min}$ of $5.33 \mathrm{mg} / \mathrm{dl}$.

Table 6. Blood glucose response (mg/dL) before and after consumption of cereals product research

\begin{tabular}{|c|c|c|c|c|c|}
\hline Subject & 0 minutes & 30 minutes & 60 minutes & 90 minutes & 120 minutes \\
\hline & \multicolumn{5}{|c|}{ Blood Glucose (mg/dL) } \\
\hline 1 & 87 & 93 & 85 & 83 & 79 \\
\hline 2 & 83 & 94 & 93 & 86 & 80 \\
\hline 3 & 96 & 106 & 96 & 91 & 80 \\
\hline 4 & 87 & 95 & 93 & 91 & 84 \\
\hline 5 & 89 & 104 & 92 & 91 & 80 \\
\hline 6 & 86 & 96 & 94 & 86 & 88 \\
\hline 7 & 93 & 115 & 95 & 87 & 81 \\
\hline 8 & 83 & 104 & 91 & 93 & 87 \\
\hline 9 & 89 & 98 & 86 & 89 & 84 \\
\hline 10 & 83 & 99 & 94 & 91 & 81 \\
\hline 11 & 99 & 102 & 101 & 100 & 95 \\
\hline Total & 975 & 1136 & 1080 & 1078 & 1039 \\
\hline Mean & 81.25 & 94.67 & 90.00 & 89.83 & 86.58 \\
\hline
\end{tabular}

Remarks:

0 minutes $=$ blood glucose after fasting from $8 \mathrm{pm}$ to $8 \mathrm{am} /$ before the consumption of cereals (except water) $30,60,90,120$ minutes $=$ blood glucose after consumption of time

Blood glucose during fasting $(0 \mathrm{~min})$ the average of the three subjects $81,33 \mathrm{mg} / \mathrm{dL}$ with the lowest was $83 \mathrm{mg} / \mathrm{dL}$, while the highest was $97 \mathrm{mg} / \mathrm{dL}$ (Table 7) Difference in the increase of blood glucose at the time before to after eating cereal at minutes to 30 at $39.83 \mathrm{mg} / \mathrm{dL}$. Average increase in blood glucose occurred after $120 \mathrm{~min}$ compared with $0 \mathrm{~min}$ of $7.08 \mathrm{mg} / \mathrm{dL}$.

Table 7. Response of blood glucose $(\mathrm{mg} / \mathrm{dL})$ before and after consumption of cereal commercial

\begin{tabular}{|c|c|c|c|c|c|}
\hline Subject & 0 minute & 30 minutes & 60 minutes & 90 minutes & 120 minutes \\
\hline & \multicolumn{5}{|c|}{ Blood glucose (mg/dL) } \\
\hline 1 & 84 & 136 & 79 & 73 & 73 \\
\hline 2 & 85 & 137 & 92 & 81 & 82 \\
\hline 3 & 93 & 111 & 95 & 91 & 87 \\
\hline 4 & 91 & 107 & 81 & 93 & 91 \\
\hline 5 & 97 & 138 & 98 & 87 & 90 \\
\hline 6 & 83 & 139 & 103 & 107 & 88 \\
\hline 7 & 95 & 140 & 109 & 88 & 85 \\
\hline 8 & 84 & 117 & 76 & 83 & 93 \\
\hline 9 & 83 & 149 & 91 & 76 & 77 \\
\hline 10 & 85 & 113 & 95 & 84 & 83 \\
\hline 11 & 96 & 137 & 93 & 91 & 92 \\
\hline Total & 976 & 1454 & 1072 & 1044 & 1061 \\
\hline Mean & 81.33 & 121.17 & 89.33 & 87.00 & 88.42 \\
\hline
\end{tabular}

Remarks:

0 minutes $=$ blood glucose after fasting from $8 \mathrm{pm}$ to $8 \mathrm{am} /$ before the consumption of cereals (except water) $30,60,90,120$ minutes $=$ blood glucose after consumption of time

Difference rise in blood glucose $30 \mathrm{~min}$ between current consumption energen cereal with product research ie $39.83 \mathrm{mg} / \mathrm{dL}: 13.42 \mathrm{mg} / \mathrm{dL}$ (Fig. 1, Table 6 and 7) Decrease in blood glucose after consumption of Energen cereal 60 minutes on average $31,84 \mathrm{mg} / \mathrm{dL}$, while the consumption of cereals product research 4.67 $\mathrm{mg} / \mathrm{dL}$. 


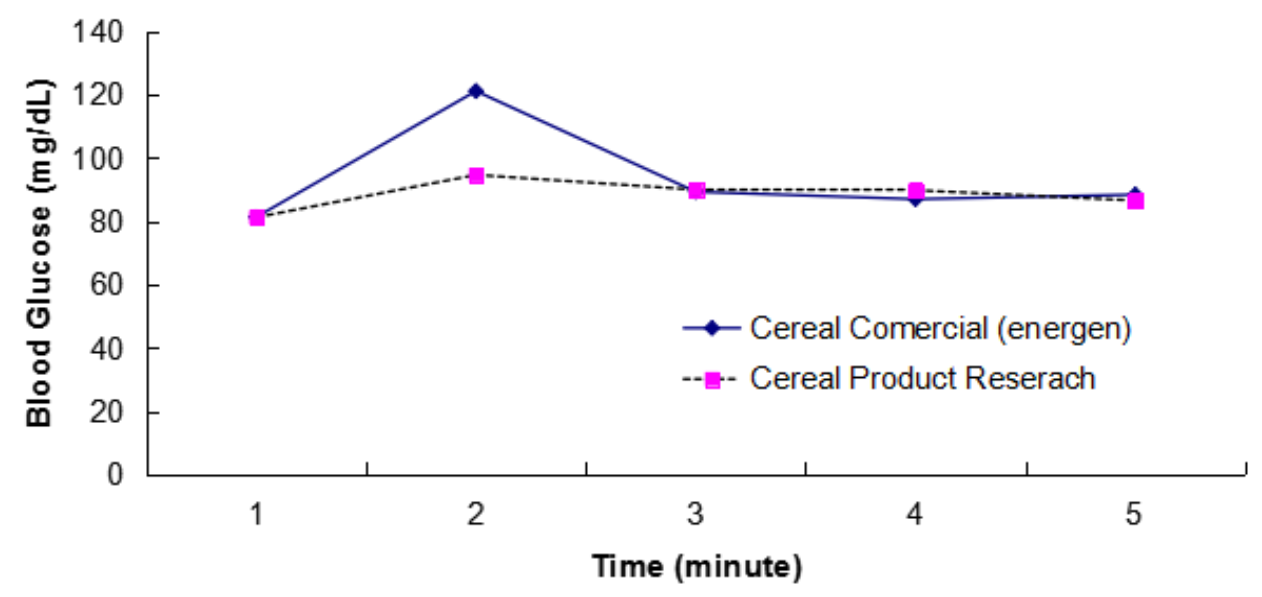

Fig. 1: Comparison of response of the average blood glucose in subjects after consumption of cereal product research and commercial product

\section{Discussion}

Phytochemical test results showed that steroids are not on lai, plant bulbs tiwai, banana weevil, haruan fish and sweet potato. Saponins found only in lai and banana weevil. Flavonoids are not detected in striatus sp, alkaloids were not detected in catfish and sweet potato. Steroid component not found in five samples (Table 1) it is caused by the distribution of the respective compounds appears to be almost mutually exclusive in the families. It is argued that these patterns might reflect differential expression of the corresponding genes that have evolved earlier in plant. The inconsistent secondary metabolite profiles mean that the systematic value of chemical characters becomes a matter of interpretation in the same way as traditional morphological markers [8]. The highest levels of carbohydrate in a row is obtained on banana weevil flour, sweet potato flour, lai, and haruan fish (Table 2), but the highest energy obtained in lai, lai this is due to higher own fat. It is because every 1 gram of fat has an energy conversion (kcal) higher at $9 \mathrm{kcal}$. Based on sensory evaluation of the most preferred is the yellow sweet potato flour (Table 4), Sue Shan et al 2005 [9] reported that the physical properties of extrudates depend closely on the flour types and barrel temperature of the extrudates.

Differences increase in blood glucose after consumption of commercial products (Energen) and product research results (Tabel 6,7 and figure 1) is attributable to several factors including the type of flour, added sugars and other compositions such as fiber. Study of Saragih et al., 2013[4] that showed differencies in reduction of blood glucose levels olso found in volunteers who consumed black adan instant rice by $14.2 \mathrm{mg} / \mathrm{dL}$, whereas the provision of a reference food (pure glucose) of $71.5 \mathrm{mg} / \mathrm{dL}$, this indicates that the reference food provides a rapid rise in glucose levels and decreased back toward normal as well with a fast time. Instead of instant rice functional black adan provide availability of blood glucose in the blood longer available (slow release). Decrease in blood glucose also depends in running one dietary compliance technology helps compliance with the diet. The new weight-loss prediction software, the which incorporates an intermittent lack of adherence, can be used to guide and inform patients on realistic levels of adherence on the basis of patient lifestyle [11]. Studies of Cho et al 2014 [10], showed prospective studies consistently showed a reduced risk of diabetes with high intakes of cereal fiber or mixtures of whole grains and bran.

When compared with cereal commercial (energen) with one 29 gram sachet packaging derived energy of $130 \mathrm{kcal}$ (equivalent to $4.48 \mathrm{kcal}$ per $1 \mathrm{gram}$ ). In this study were obtained every $1 \mathrm{~g}$ equivalent to $3.56 \mathrm{kcal}$. Then for one cereal packaging $29 \mathrm{~g}$ product of this study obtained $104 \mathrm{kcal}$ of energy, as the food products of this research product cereal product energy research under commercial cereals (Energen). This is due to no addition of sugar in the product seral in this study. Differences in the amount of calories and sugar contained in food would lead to differences in blood glucose response as also found in this study (Fig.1). Effect of cereal in lowering blood sugar levels would not be effective if it is not accompanied by a proper diet. The development of ingredients for a functional food could be an interesting addition to the current dietary recommendations. Study of Gilmore et al, 2014 [12], showed that test the accuracy and precision of the intake-balance method to estimate EI during weight gain induced by overfeeding, showed the intake-balance method can be used to estimates of energy intake (EI)during a period of weight gain as a result of $40 \%$ overfeeding in individuals who are inpatients or free-living with only a slight underestimate of actual EI by $0.2-3.8 \%$. In addition to the consumption of sugar and fat, meat and food process may also affect health. High processed red meat consumption is associated with increased risk of cardiovascular disease [13]. 


\section{Conclusion}

Flour of banana weevil has components flavonoids, phenols and alkaloids. Flour lai has saponins, flavonoids, phenols and alkaloids. Lepiu flour has had saponins, flavonoids, phenols and alkaloids. Yellow sweet potato flour has flavonoids, phenols and alkaloids while tiwai Extract has flavonoids, phenols and alkaloids do not have steroids and saponins. Based on the test results by the panelists sensories most preferred flour is yellow sweet potato flour, then bananas, lai, and haruan fish. Composite flour is most preferred by the panelists was the comparison lai; banana weevil; haruan fish; sweet potato(1:2:1:2). Nutrient composition of cereal product research have carbohydrates $(75.22 \%)$, protein $(6.57 \%)$, fat $(3.26 \%)$, water content $(10.15 \%)$, ash content $(1.45 \%)$, crude fiber $(3.35 \%)$ amd energy $(356,5 \mathrm{kcal})$. The increase in blood glucose after consumption of 30 minutes was higher in commercial cereals $39.83 \mathrm{mg} / \mathrm{dL}$ compared with cereal product research that is $13.42 \mathrm{mg} / \mathrm{dL}$. A decrease in blood glucose after consumption of 60 minutes subjects were higher in commercial products $31.84 \mathrm{mg} / \mathrm{dL}$, while cereal product research to $4.67 \mathrm{mg} / \mathrm{dL}$. These results indicate that cereals these results slower release of blood glucose, so the potential for food in diabetic patients.

\section{Acknowledgements}

Thank submitted to the Directorate General of Higher Education of the Republic of Indonesia on Aid Scheme Fundamental Research Fund by 2014-2015.

\section{References}

[1]. B. Saragih, M.Pasiakan , Saraheni, and D. Wahyudi, Effect of herbal drink plants tiwai (Eleutherine americana Merr) on lipid Profile of hypercholesterolemia patients, International Food Research Journal 21(3), 2014, 1163-1167

[2]. A. Drewnowski and C.D.Rehm, Consumption of added sugars among US children and adults by food purchase location and food source. Am J Clin Nutr 100, 2014, 901-907; doi:10.3945/ajcn.114.089458

[3]. B. Saragih, Analisys of quality banana weevil flour from various and difference age, Jurnal TIBBS Teknologi Industri Boga dan Busana. 9 (1), 2013, 22-29.

[4]. B. Saragih, Marwati, B. Saragih, H. Suprapto, and M. Rachmawati, Effect of various types of herbs on sensory properties and blood glucose response Adan instant black rice. International Journal of Science and Engineering (IJSE), 5 (1), 2013, :42-48

[5]. SV. Gupta, N.Yamada, TV. Fungwe and P. Khosla, Replacing 40\% of dietary animal fat with vegetable oli in associated with lower HDL cholesterol and higher cholesterol ester transfer protein in Monkeys Fed sufficient linoleic acids, J Nutr 133, 2003, 2600-2606

[6]. AOAC, Association of Official Analytical Chemists. Official method of Analysis (18th edition). (AOAC Intl., USA. 2006).

[7]. J.N.Nwosu, C.I.Owuamanam, G.C.Omeire and C.C. Eke, Quality parameters of bread produced from substitution of wheat flour with cassava flour using soybean as an improver. American Journal of Research Communication, 2(3), 2014, :99-118

[8]. M.Wink, Evolution of secondary metabolites from an ecological and molecular phylogenetic perspective". Phytochemistry. 64 (1), 2003, 3-19. doi:10.1016/S0031-9422(03)00300-5. PMID 12946402.

[9]. L.Sue Shan, R.Sulaiman, M.Sanny, and Z.A.Nur Hanani, Effect of extrusion barrel temperatures on residence time and physical properties of various flour extrudates. International Food Research Journal 22(3), 2016, 965-972

[10]. S.S.Cho, Lu Qi, G.C.Fahey Jr , and D.M.Klurfeld, Consumption of cereal fiber, mixtures of whole grains and bran, and whole grains and risk reduction in type 2 diabetes, obesity, and cardiovascular disease, 2014, www. ajcn.nutrition.org (access $5^{\text {th }}$ September 2014)

[11]. D.M.Thomas, C.K.Martin, L.M.Redman, S.B.Heymsfield, S.Lettieri, J.A.Levine, C. Bouchard, and D.A. Schoeller , Effect of dietary adherence on the body weight plateau: a mathematical model incorporating intermittent compliance with energy intake prescription, Am J Clin Nutr 100, 2014, 787-795; doi:10.3945/ajcn.113.079822

[12]. L.A.Gilmore, E.Ravussin, G.A.Bray. H. Han and L.M.Redman, An objective estimate of energy intake during weight gain using the intake-balance method, Am J Clin Nutr 2014 100: 806-812; doi:10.3945/ajcn.114.087122

[13]. M.Lajous, A.Bijon, G.Fagherazzi, E. Rossignol , M.C.B.Ruault, and F.C.Chapelon,Processed and unprocessed red meat consumption and hypertension in women, Am J Clin Nutr 100, 2014, 948-952; doi:10.3945/ajcn.113.080598

[14]. J.B. Miller, K. Foster-Powel and S. Colagiuri. The GI Factor:The GI Solution. Hodder and Stougton. Hodder Headline `Australia Pty Limitted.1996.

[15]. K.Sahira Banu and L.Cathrine, General Techniques Involved in Phytochemical Analysis, International Journal of Advanced Research in Chemical Science (IJARCS). 2 (4), 2015, 25-32 